\title{
Adsorbents as antiendotoxin agents in experimental colitis
}

\author{
K R Gardiner, N H Anderson, M D McCaigue, P J Erwin, M I Halliday, B J Rowlands
}

\begin{abstract}
The intestinal mucosa protects the body from a large reservoir of intraluminal pathogenic bacteria and endotoxins. This mucosal barrier is disrupted by the inflammation and ulceration of inflammatory bowel disease and may permit the absorption of toxic bacterial products. Systemic endotoxaemia has been demonstrated in ulcerative colitis and Crohn's disease and correlates with the extent and activity of disease. In this study the efficacy of adsorbents as antiendotoxin agents in a hapten induced rat model of colitis is investigated. Induction of colitis was associated with systemic endotoxaemia. Enteral administration of terra fullonica and kaolin, but not of charcoal, significantly reduced systemic endotoxaemia (terra fullonica $4.2(1.40) \mathrm{pg} / \mathrm{ml}$; kaolin $5.29(1.86) \mathrm{pg} / \mathrm{ml}$; charcoal $32.7(16.6)$ $\mathrm{pg} / \mathrm{ml}$; water $39.8(12.6) \mathrm{pg} / \mathrm{ml})$. Data expressed as mean (SE). With increasing severity of colitis, there was a decreasing ability of adsorbent therapy (terra fullonica) to control systemic endotoxaemia. Enteral administration of adsorbents controls gut derived systemic endotoxaemia in experimental colitis. in animals and may be a useful antiendotoxin treatment in patients with inflammatory bowel disease.

(Gut 1993; 34: 51-55)
\end{abstract}

A role for bacteria or their products in the aetiology and pathogenesis of inflammatory bowel disease was suggested over 50 years ago but still remains unproven. In 1937 Shwartzman reported that a local reactivity to bacterial products might be important in the aetiopathogenesis of chronic ulcerative colitis. ${ }^{1}$ Colonic inflammation has been experimentally induced by subserosal injection of bacterial lysate, and by intramucosal injection or intrarectal instillation of Escherichia coli endotoxin. ${ }^{2-4}$ Portal and systemic endotoxaemia have been documented in Crohn's disease and ulcerative colitis on many occasions. ${ }^{5-17}$ Systemic endotoxaemia correlates positively with the presence and extent of intestinal ulceration and with the activity of the disease; and may contribute to the disease activity, the development of toxic megacolon, abnormalities of liver histology and other extraintestinal manifestations of inflammatory bowel disease. ${ }^{7-9} 1318$

Attempts have been made to treat systemic endotoxaemia in inflammatory bowel disease. Shwartzman treated 21 patients suffering from ulcerative colitis with a 'phenomenon neutralising anti-colon serum', obtaining good results in 18.' Other successful treatments of systemic endotoxaemia reported in inflammatory bowel disease include polymyxin, haemosorption, and whole gut irrigation with saline and 5-aminosalicylic acid. ${ }^{9} 131519$

Nolan and Ali recognised the possible contribution of luminal bacterial endotoxins to the activity of inflammatory bowel disease and suggested that luminal endotoxins could be inactivated by an enterally administered non-specific binding agent. ${ }^{20}$ Ditter et al have shown that adsorbents such as bentonite, kaopectate, and charcoal possess in vivo and in vitro antiendotoxin activity. ${ }^{21}$

Enteral administration of adsorbents, if effective in inflammatory bowel disease, would represent a less invasive and a safer form of therapy than those previously used. ${ }^{131519}$ The purpose of this study is to investigate the ability of adsorbents, administered enterally, to reduce systemic endotoxaemia in a hapten induced model of colitis. This model has been well characterised and possesses clinical, biochemical and pathological similarities to colonic Crohn's disease. $^{22}$ We have recently shown that significant portal and systemic endotoxaemia occurs in this model over a period of three weeks. ${ }^{23}$

\section{Methods}

\section{ANIMALS}

Male Wistar rats weighing $300-400 \mathrm{~g}$, obtained from our breeding colony, were used in this study. The animals were housed in groups of four in rack mounted cages in a room with controlled temperature $\left(22^{\circ} \mathrm{C}\right)$ and light dark cycle (12 hours: 12 hours). Standard rat pelleted formula (Robert Morton and Co Ltd, Ballymena, N Ireland, UK) and tap water were provided ad libitum.

\section{INDUCTION OF COLITIS}

After a 16 hour fast, rats ( $n=16 /$ treatment group) were sedated by an intramuscular injection of $0 \cdot 1$ $\mathrm{ml}$ Hypnorm (fentanyl citrate $0.315 \mathrm{mg} / \mathrm{ml}$, fluanisone $10 \mathrm{mg} / \mathrm{ml}$; Janssen Pharmaceutical Ltd, Oxford, UK) and $0.25 \mathrm{mg}$ diazepam. A 5 gauge polypropylene catheter (Bardic feeding tube 1732, Bard Ltd, Sunderland, UK) was lubricated with jelly and inserted $10-12 \mathrm{~cm}$ through the anal canal into the colon to lie at, or just proximal to, the splenic flexure. Twenty five milligrams 2,4,6-trinitrobenzenesulphonic acid (Sigma Chemical Co Ltd, Poole, Dorset, UK) mixed with $0.25 \mathrm{ml} 30 \%$ ethanol was instilled through the catheter which was flushed with 0.5 $\mathrm{ml}$ air to expel all of the inducing agent. After instillation the rats were supported in a supine Trendelenburg position until recovery from the 
anaesthetic to prevent immediate anal leakage of the instillate.

Two additional groups of rats were studied. One group $(n=14)$ received $0.5 \mathrm{ml} 0.9 \%$ saline (healthy controls) and the other $(n=$ eight $)$ received $35 \mathrm{mg}$ trinitrobenzenesulphonic acid in $30 \%$ ethanol by intracolonic instillation.

\section{ADMINISTRATION OF ADSORBENTS}

Commencing five days after induction of colitis and continued twice daily for three days until day 8 , the rats received by intragastric instillation either Kaopectate (105 mg kaolin, Upjohn Ltd, Crawley, UK), Medicoal (25 mg activated charcoal, Lundbeck Ltd, Luton, UK), terra fullonica (300 mg hydrated aluminium silicate, ICI Pharmaceuticals, Wilmslow, UK), or tap water (disease controls). These doses were based on the same proportion $(1 / 200)$ of the recommended doses for adult patients.

The healthy control group received no additional treatment. The group which initially received $35 \mathrm{mg}$ trinitrobenzenesulphonic acid in ethanol was treated with $300 \mathrm{mg}$ terra fullonica bd for three days.

\section{COLLECTION OF BLOOD}

On day 8 , the rats were sedated as before and weighed. After cleaning the chest wall with Hibitane (ICI Pharmaceuticals, Wilmslow, UK), blood was collected by closed chest cardiac puncture (to avoid handling of the bowel during collection of blood). Blood for endotoxin estimation was aliquoted into sterile and endotoxin free borosilicate glass tubes containing heparin 20 $\mathrm{IU} / \mathrm{ml}$ and immediately stored in ice until centrifuged. Blood was also collected for serum lactate and pyruvate determinations (Sigma diagnostics, Sigma Chemical Co, Ltd, Poole, UK), serum albumin and liver function tests.

\section{ASSESSMENT OF COLITIS}

A midline laparotomy was made, the terminal ileum and rectum divided and the colon removed. The colon was opened longitudinally and cleaned of faeces by gentle irrigation with water.

\section{Colon macroscopic score}

The freshly opened colon was pinned out and examined under a Leitz dissecting microscope by two independent observers. The extent of mucosal damage was assessed using a modification of the colon macroscopic scoring system of Wallace $e^{2} a^{24}$ (Table I).

\section{TABLE I Colon macroscopic score (CMS)}

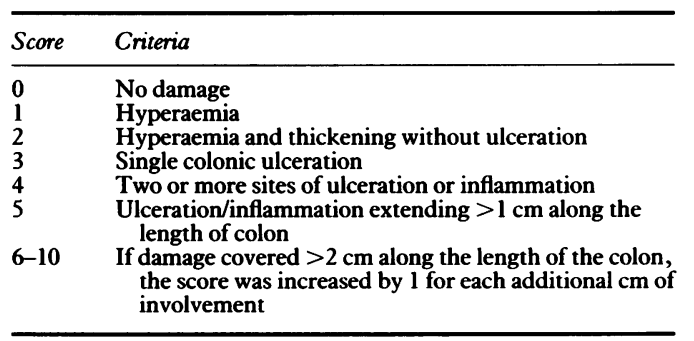

Based on the scoring system of Wallace et al. ${ }^{24}$
Colon weight and colon weight/body weight ratio

After scoring, the distal $8 \mathrm{~cm}$ of the colon were blotted dry and weighed using a Sartorius laboratory balance. The colon weight/body weight ratio was calculated as an increase in this ratio has been shown to be an accurate marker of colonic inflammation..$^{25}$

\section{Colon histology}

The tissue was fixed using Brunnels primary fixative (Laboratory Supplies and Instruments, Antrim, UK), processed by conventional methods and then embedded in paraffin. $5 \mu \mathrm{m}$ sections were stained with haematoxylin and eosin and examined using a Leitz Laborlux $\mathrm{K}$ microscope.

\section{DETERMINATION OF SYSTEMIC ENDOTOXIN CONCENTRATION}

Systemic blood was centrifuged for 10 minutes at $4^{\circ} \mathrm{C}$ and $460 \mathrm{~g}$ and plasma aliquoted using sterile individually wrapped transfer pipettes into sterile cryotubes (three per blood sample) (Nunc 363401, Intermed, Denmark). The plasma was stored at $-80^{\circ} \mathrm{C}$ until assayed for endotoxin using a modified limulus amoebocyte lysate assay (Coatest Endotoxin, Kabi Diagnostica, Molndal, Sweden). Endotoxin stock solution was diluted with sterile pyrogen-free water to give standards of $0.1,0.25,0.5$, and 1.0 endotoxin units $/ \mathrm{ml}$ ( 1 endotoxin unit $=83 \mathrm{pg} / \mathrm{ml}$ ). To $50 \mu \mathrm{l}$ of each of the standards, $50 \mu \mathrm{l}$ of plasma pooled from healthy rats and $400 \mu l$ of sterile water were added. Test plasma samples $(50 \mu \mathrm{l})$ were also diluted 1:10 with sterile water. The standards and test samples were heated in a water bath $\left(75^{\circ} \mathrm{C}\right)$ for 10 minutes, allowed to cool for 15 minutes, and mixed vigorously before use.

For the test procedure, $25 \mu \mathrm{l}$ from each of the standard and test sample tubes were dispensed into duplicate reaction tubes. To each tube, 25 $\mu l$ of reconstituted limulus amoebocyte lysate was added, before incubation for $\mathbf{3 5}$ minutes at $37^{\circ} \mathrm{C}$. After this incubation, $50 \mu \mathrm{l}$ of substrate solution was added and the reaction stopped 10 minutes later by addition of $50 \mu \mathrm{l} 20 \%$ acetic acid. The contents of each tube were transferred to a microtitre plate and absorbance read at 405 $\mathrm{nm}$. The concentration of endotoxin in the test plasma samples (average of the duplicates) was determined from the standard curve. The assay has a sensitivity of $8.3 \mathrm{pg} / \mathrm{ml}$ and is linear from $8 \cdot 3-100 \mathrm{pg} / \mathrm{ml}$.

\section{STATISTICAL ANALYSIS}

Data analysis was performed on a Macintosh LC computer using the Mann Whitney $U$ test and Student's $t$ test (StatWorks). Probabilities less than $\mathbf{0 . 0 5}$ were considered significant.

\section{Results}

\section{CLINICAL FEATURES}

The trinitrobenzenesulphonic acid/ethanol treated rats showed weight loss, diarrhoea, piloerection, reduced fluid intake, lack of preen- 
TABLE II Survival and colon inflammation assessment

\begin{tabular}{|c|c|c|c|c|}
\hline Treatment group & $\begin{array}{l}\text { Survival } \\
(\%)\end{array}$ & $\begin{array}{l}\text { Colon } \\
\text { macroscopic } \\
\text { score }\end{array}$ & $\begin{array}{l}\text { Colon } \\
\text { weight } \\
\text { (g) }\end{array}$ & $\begin{array}{l}\text { Colon } \\
\text { weight }(\mathrm{g}) / \\
\text { body } \\
\text { weight }(\mathrm{kg})\end{array}$ \\
\hline $\begin{array}{l}\text { Kaolin }(n=16) \\
\text { Charcoal }(n=16) \\
\text { Terra fullonica }(n=16) \\
\text { Water }(n=16) \\
\text { Intracolonic saline }(n=14)\end{array}$ & $\begin{array}{r}88 \\
88 \\
100 \\
94 \\
100\end{array}$ & $\begin{array}{l}4 \cdot 44(0 \cdot 46)^{\star} \\
4 \cdot 44(0 \cdot 59)^{\star} \\
5 \cdot 38(0 \cdot 18)^{\star} \\
4 \cdot 17(0 \cdot 61)^{\star} \\
0 \cdot 60(0 \cdot 20)\end{array}$ & $\begin{array}{l}2.03(0.45)^{\star} \\
1.85(0.39)^{\star} \\
2.38(0 \cdot 23)^{\star} \\
1.63(0.39)^{\star} \\
0.76(0.03)\end{array}$ & $\begin{array}{l}5.82(1 \cdot 31)^{\star} \\
5.45(1 \cdot 34)^{\star} \\
7 \cdot 79(0.69)^{\star} \\
4.98(1 \cdot 30)^{\star} \\
2 \cdot 01(0.08)\end{array}$ \\
\hline
\end{tabular}

Data are expressed as mean (SE)

Significance: colitic $v$ saline ${ }^{\star}=\mathrm{p}<0.05$;

between treatment groups: no significant difference in colon inflammation.

(Mann Whitney for colon macroscopic score; Student's $t$ test for colon weight and colon/body weight ratio).

ing, and a reduced level of activity. Survival in each group is shown in Table II.

\section{COLONIC INFLAMMATION}

Significant colon inflammation was induced in the colitic groups compared with the saline treated animals as measured by the colon macroscopic score, colon weight and colon weight body weight ratio $(p<0.05)$ (Table II). There was no significant difference in the severity of the colonic inflammation between the treatment groups.

Histological examination showed broad based mucosal ulcers with a surface layer of necrotic ulcer slough. Occasional islands of regenerative mucosa were present. The inflammatory infiltrate associated with the ulcers was mixed, consisting of neutrophils, eosinophils, lymphocytes, and plasma cells. Occasional epithelioid granulomata were seen in the ulcer base. The inflammation extended the full thickness of the bowel wall and there was periocolic wrapping of fat. No qualitative differences were observed in the histological appearances of the colon in the treatment groups and no colonic histological abnormality was identified in the saline treated control group.

\section{SYSTEMIC ENDOTOXAEMIA}

Induction of colitis by intracolonic instillation of $25 \mathrm{mg}$ trinitrobenzenesulphonic acid in 30\% ethanol was associated with systemic endotoxaemia (healthy controls $4.0(1.2) \mathrm{pg} / \mathrm{ml}$; disease controls $39.8(12.6) \mathrm{pg} / \mathrm{ml}, \mathrm{p}<0.05$ Mann Whitney).

Enteral administration of kaopectate and terra fullonica over a period of three days produced a significant reduction in systemic endotoxaemia when compared with control therapy (Table III). Kaopectate and terra fullonica appeared equally effective in their endotoxin-binding activity and eliminated endotoxins from the systemic circula-

TABLE III Systemic endotoxaemia and assessment of illness

\begin{tabular}{lclll}
\hline & $\begin{array}{l}\text { Systemic } \\
\text { endotoxin } \\
\text { conc }(p g / m l)\end{array}$ & $\begin{array}{l}\text { Serum } \\
\text { lactate conc } \\
(\text { mmolll })\end{array}$ & $\begin{array}{l}\text { Serum } \\
\text { alkaline } \\
\text { phosphatase } \\
(I U / l)\end{array}$ & $\begin{array}{l}\text { Serum } \\
\text { albumin } \\
\text { conc }(g / l)\end{array}$ \\
Treatment group & $5 \cdot 29(1 \cdot 86)^{\star}$ & $2 \cdot 98(0 \cdot 38)$ & $144 \cdot 2(12 \cdot 1)$ & $31 \cdot 2(1 \cdot 1)$ \\
\hline Kaolin $(\mathrm{n}=14)$ & $32 \cdot 7(16 \cdot 6)$ & $3 \cdot 01(0 \cdot 58)$ & $170 \cdot 0(14 \cdot 1)$ & $30 \cdot 7(1 \cdot 1)$ \\
Charcoal $(\mathrm{n}=14)$ & $4 \cdot 2(1 \cdot 40)^{\star}$ & $2 \cdot 15(0 \cdot 20)$ & $175 \cdot 9(11 \cdot 0)$ & $27 \cdot 2(0 \cdot 8) \dagger$ \\
Terra fullonica $(\mathrm{n}=16)$ & $39 \cdot 8(12 \cdot 6)$ & $2 \cdot 61(0 \cdot 33)$ & $168 \cdot 7(7 \cdot 7)$ & $30 \cdot 1(0 \cdot 7)$ \\
Water $(\mathrm{n}=15)$ & & &
\end{tabular}

Data are expressed as mean (SE)

Significance: $v$ controls ${ }^{\star}=\mathrm{p}<0.05$ (Mann Whitney), $\dagger=\mathrm{p}=0.01$ ( $t$ test $)$ tion (systemic endotoxin concentrations not significantly different from healthy controls). Enteral administration of activated charcoal was not effective in reducing systemic endotoxaemia at a dose of $25 \mathrm{mg}$ bd in this model. There were no significant differences in the serum lactate, pyruvate, or alkaline phosphatase concentrations between the treatment groups. There was a modest but significant decrease in serum albumin concentration in the terra fullonica group (Table III).

Intracolonic instillation of $35 \mathrm{mg}$ trinitrobenzenesulphonic acid in ethanol in a further group of eight animals induced a more severe colitis (35 mg trinitrobenzenesulphonic acid/ ethanol, colon macroscopic score 7.50 (0.27); $25 \mathrm{mg}$ trinitrobenzenesulphonic acid/ethanol, colon macroscopic score 5.38 (0.18), p $<0.05$ Mann Whitney). In this group the same therapeutic regime of enteral terra fullonica did not eliminate endotoxaemia ( $35 \mathrm{mg}$ trinitrobenzenesulphonic acid/ethanol, endotoxin conc 35.9 $(13.3) \mathrm{pg} / \mathrm{ml} ; 25 \mathrm{mg}$ trinitrobenzenesulphonic acid/ethanol, endotoxin conc $4 \cdot 2(1 \cdot 4) \mathrm{pg} / \mathrm{ml})$.

The Figure shows the systemic endotoxin concentrations plotted against colon macroscopic score for the disease control group (water) and the combined terra fullonica groups ( 25 and $35 \mathrm{mg}$ trinitrobenzenesulphonic acid/ethanol). With increasing colonic damage there was a greater incidence of endotoxaemia $(>10 \mathrm{pg} / \mathrm{ml})$ and the circulating concentrations of endotoxin were higher. With less severe colonic damage, terra fullonica was able to prevent the occurrence of systemic endotoxaemia. As the colonic damage exceeded 6 on the colon macroscopic score, enteral administration of terra fullonica became less effective as an antiendotoxin measure (colon macroscopic score $\leq 6$, endotoxin conc 4.9 (1.4); colon macroscopic score $>6$, endotoxin conc 35.9 (13.3): $p<0.05$ Mann Whitney).

\section{Discussion}

It has been suggested that, in inflammatory bowel disease, endotoxins originating from the intestinal flora cross the disrupted intestinal mucosal barrier and enter the portal circulation. If the hepatic capacity to eliminate portal endotoxins is exceeded, spillover into the systemic

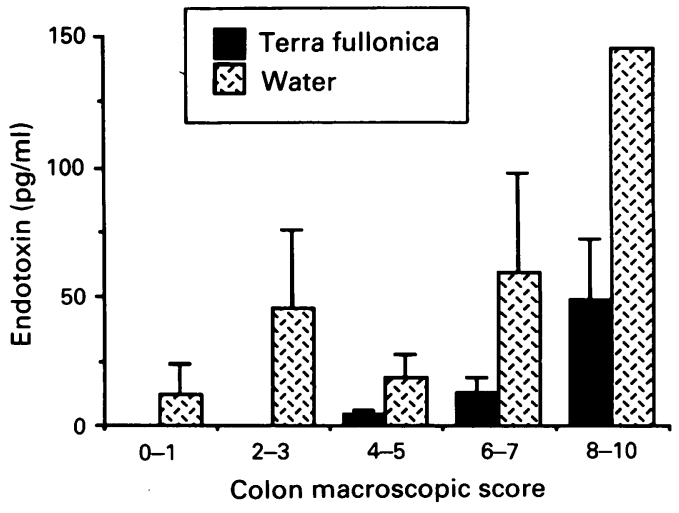

Endotoxin concentrations after treatment with water and terra fullonica. 
circulation will occur. ${ }^{26}$ Endotoxins could then activate monocytes with the release of cytokines (tumour necrosis factor and interleukin-1) resulting in an inflammatory cascade and the systemic clinical and biochemical features of inflammatory bowel disease.

Induction of colitis, by the intracolonic instillation of trinitrobenzenesulphonic acid/ ethanol, acetic acid, or ethanol or by the oral administration of carrageenan is associated with systemic endotoxaemia. ${ }^{27} 28$ Systemic endotoxaemia is a feature of the colitis rather than the inducing agent. The trinitrobenzenesulphonic acid/ethanol model of colitis was chosen because of its immunological basis, relative chronicity and the similar range of systemic endotoxin concentrations to those found in inflammatory bowel disease $(0-150 \mathrm{pg} / \mathrm{ml}) .{ }^{16} 17$

Kaolin (powdered naturally hydrated aluminium silicate) is used as an antidiarrhoeal agent, acting by adsorption of bacteria and toxins. $^{29}$ Terra fullonica (montmorillonite: hydrated aluminium silicate and calcium carbonate) is used as an adsorbent in toiletries, in industry and for paraquat poisoning. Activated charcoal is a non-specific adsorbent used for treatment of most ingested poisons and for haemofiltration for endotoxaemia. ${ }^{30}$

The enteral administration of kaolin and terra fullonica produced a significant reduction in systemic endotoxaemia compared with the disease control group (water) in this experimental model of colitis. The systemic endotoxin concentrations in these treated groups were not significantly different from healthy animals $(4 \cdot 0$ $(1 \cdot 2) \mathrm{pg} / \mathrm{ml})$. The endotoxin concentrations in these animals were below the limit of sensitivity of the assay $(8.3 \mathrm{pg} / \mathrm{ml})$ and are considered to be not significant. Charcoal was not found to be effective as an antiendotoxin agent.

These results are similar to those reported by Ditter $e t a l .{ }^{21}$ They demonstrated the capacity of kaolin, kaopectate, bentonite (aluminium silicate), and carbomedicinalis (activated charcoal) to bind endotoxin in vitro. In an acute experimental model of gut derived systemic endotoxaemia in mice, produced by simultaneous intravenous injection of serotonin and intragastric instillation of endotoxin, they found bentonite (hydrated aluminium silicate: $75 \mathrm{mg}$ ), kaopectate $(150 \mathrm{mg})$, and charcoal $(25 \mathrm{mg})$ to be effective in reducing endotoxaemia. In this study, $300 \mathrm{mg}$ bd terra fullonica and $105 \mathrm{mg}$ bd kaolin were effective in reducing systemic endotoxaemia in the colitic rat to concentrations not different from healthy animals.

It is probable that the colonic ulceration in this model and the larger size of the colonic pool of endotoxin would cause higher concentrations of systemic endotoxin than the acute model of iv serotonin and ig endotoxin. It may be that higher doses of charcoal (equivalent to those used of terra fullonica and kaopectate) would be as effective in this model. The effectiveness of charcoal in the colon has been questioned, however, as passage through the upper gastrointestinal tract generally saturates the adsorptive capacity of the drug..$^{29}$ Enteral administration of kaolin in combination with kanamycin has also been shown to be effective in the prevention of endotoxaemia caused by heat stress and intestinal ischaemia in primates. ${ }^{3132}$

In the second part of this study, a higher dose of the inducing agent (trinitrobenzenesulphonic acid/ethanol) was administered ( $35 \mathrm{mg} v 25 \mathrm{mg}$ ), producing significantly more severe colonic damage. The same dose of terra fullonica $(300$ $\mathrm{mg}$ bd) was ineffective in eliminating systemic endotoxaemia with this degree of colonic inflammation. The enteral administration of terra fullonica shifted the curve of spillover endotoxaemia seen in disease controls to the right (Figure). It would therefore appear that in determining the dose of adsorbent required, it is necessary to take into account the size of the intestinal endotoxin pool, the extent of dysfunction of the gut mucosal barrier and the adsorptive capacity of the agent. A considerable excess of the adsorbent would seem advisable.

No improvement in weight gain, serum albumin, lactate or alkaline phosphatase concentrations was demonstrated in the treatment groups compared with the disease control group. This present study was not designed to assess the biological significance of endotoxaemia, however, nor the treatment of colitis. Longer treatment and study periods would be necessary to investigate the influence of adsorbents on the severity and resolution of the colitis.

In conclusion, we have shown that the enteral administration of adsorbents is effective in treating systemic endotoxaemia in an experimental model of colitis. Their effectiveness in this model and in three other models of gut derived endotoxaemia would indicate that these adsorbents may be successful in treating or preventing systemic endotoxaemia in inflammatory bowel disease. ${ }^{213132}$ This in vivo study and the in vivo and in vitro studies of Ditter et al have shown that hydrated aluminium silicate is the most useful. ${ }^{21}$ The benefits of such treatment may be the prevention of relapses of inflammatory bowel disease and the reduction of systemic illness during chronic relapses.

This work was supported by a research grant from the Eastern This work was supported by a research grant from

Presented at the 1991 Annual Meeting of the Society for Surgery Presented at the 1991 Annual Meeting of the Society for Surgery
of the Alimentary Tract in New Orleans [Abstract] ( $A m \mathcal{F}$ Surg of the Alimentary

1 Shwartzman G. Phenomenon of local tissue reactivity and its immunological, pathological and clinical significance. New York: Paul P Hoeber Inc, 1937: 461.

2 Kirsner JB, Goldgraber MB. The Shwartzman phenomenon in the colon of rabbits: A serial histological study A M A Arch Path 1959; 58: 539-52.

3 Patterson M, Terrell JC, Waldron RL, O'Bryan BC. The Shwartzman phenomenon in the colon of rabbits. The effects of epinephrine, norepinephrine and mecholyl. Am $\mathcal{J}$ Dig Dis 1963; 8: 213-21.

4 Hotta T, Yoshida N, Yoshikawa T, Sugino S, Kondo M. Lipopolysaccharide-induced colitis in rabbits. Res Exp Med $1986 ; 186: 61-9$.

5 Tai C. Clinical and experimental endotoxemia related to the intestinal ischemia detection of endotoxin by means of radioimmunoassay. $7 p n \mathcal{F}$ Med Sci Biol 1974; 27: 111-4.

6 Jacob AI, Goldberg PK, Bloom N, Degedshein GA, Kozimm PJ. Endotoxin and bacteria in portal blood. Gastroenterolog 1977; 72: 1268-70.

7 Aoki K. A study of endotoxemia in ulcerative colitis and Crohn's disease. I. Clinical study. Acta Med Okayama 1978; 32: $147-58$.

8 Colin R, Grancher T, Lemeland J-F, Hecketsweiler $P$ Galmiche J-P, Le Grix A, et al. Recherche d'une endotoxinemie dans les entero-colites inflammatoires cryptotoxinemie dans les entero-colites inflammatoir

$9 \mathrm{Liehr} \mathrm{H}$. The limulus assay for endotoxaemia as applied in gastroenterology. In: Cohen E, ed. Biomedical applications of the Horseshoe Crab (Limulidae). New York: Liss, 1979. 309-20.

10 Juhlin L, Krause U, Shelley WB. Endotoxin-induced micro- 
clots in ulcerative colitis and Crohn's disease. Scand $\mathcal{F}$ Gastroenterol 1980; 15: 311-4.

11 Palmer KR, Duerden BI, Holdsworth CD. Bacteriological and endotoxin studies in cases of ulcerative colitis submitted to surgery. Gut 1980; $21: 851-4$.

12 Wellmann W, Fink PC, Kubale R, Benner F. Endotoxinämie bei entzündlichen Darmerkrankungen. Verh Dtsch Ges Inn

13 Wellmann W, Fink PC, Benner F, Schmidt FW. Endotoxaemia in active Crohn's disease. Treatment with whole gut irrigation and 5-aminosalicylic acid. Gut 1986; 27: $814-20$.

14 Kelley CJ, Ingoldby CJH, Blenkharn JI, Wood CB. Colonoscopy related endotoxemia. Surg Gynecol Obstet 1985; 161: $332-4$

15 Kirkin BV, Fomin SA, Ivanov AF, Eroshkina TD, Mussin II, Khalif IL, et al. Efficiency of hemosorption in treatment of patients with ulcerative colitis. Biomat Artif Cells Artif Organs 1987; 15: 271-9.

16 Busch J, Hammer M, Brunkhorst R, Wagner P. Endotoxinbestimmung bei entzundlich-rheumatischen
Erkrankungen - Der einfluss nichtsteroidaler antiErkrankungen - Der einfluss nichtsteroidaler anti-
phlogistika auf die darmpermeabilitat. Z Rheumatol 1988;

17 Gardiner KR, Barclay GR, McCaigue MD, Erwin PJ, Stephens S, Halliday MI, et al. Endotoxin, tumour necrosis factor and anti-core glycolipid antibodies in inflammatory bowel disease. $B r \mathcal{F}$ Surg 1991; 78: 1488A.

18 Nolan JP. Endotoxin, reticuloendothelial function and liver injury. Hepatology 1981; 1: 458-65.

19 Wellmann W, Fink PC, Schmidt FW. Whole-gut irrigation as antiendotoxinaemic therapy in inflammatory bowel disease. Hepatogastroenterology 1984; 31:91-3.

20 Nolan JP, Ali MV. Effect of cholestyramine on endotoxin toxicity and absorption. Dig Dis 1972;17: 161-6.

21 Ditter B, Urbaschek R, Urbaschek B. Ability of various adsorbents to bind endotoxins in vitro and to prevent orally induced endotoxaemia in mice. Gastroenterology 1983; 84: 1547-52.
22 Morris GP, Beck PL, Herridge MS, Depew WT, Szewczuk $M R$, Wallace JL. Hapten-induced model of chronic inflammation and ulceration in the rat colon. Gastroenterology 1989; 96: 795-803.

23 Gardiner KR, Anderson NH, McCaigue MD, Halliday MI, Rowlands BJ. Systemic endotoxaemia in experimental
colitis and following treatment with oral lactulose. Brf Surg colitis and following

24 Wallace JL, MacNaughton WK, Morris GP, Beck PL. Inhibition of leukotreine synthesis markedly accelerates healing in a rat model of inflammatory bowel disease. Gastroenterology 1989; 96: 29-36.

25 Rolandelli RH, Saul SH, Settle RG, Jacobs DO, Trerotola SO, Rombeau JL. Comparison of parenteral nutrition and enteral feeding with pectin in experimental colitis in the rat. Am F Clin Nutr 1988; 47: 715-21.

26 Prytz H, Holst-Christensen J, Korner B, Liehr H. Portal venous and systemic endotoxaemia in patients without liver disease and systemic endotoxaemia in patients with cirrhosis. Scand f Gastroenterol 1976; 11: 857-63.

27 Gardiner KR, Anderson NH, McCaigue MD, Erwin PJ, Halliday MI, Rowlands BJ. Systemic endotoxaemia occurs in experimental colitis. $\operatorname{Ir} \mathcal{F}$ Med $S c i$ (in press).

28 Aoki K. A study of endotoxemia in ulcerative colitis and Crohn's disease. II. Experimental study. Acta Med Okayama 1978; 32: 207-16.

29 AHSF Drug Information. McEvoy GK, ed. Bethesda, MD: American Society of Hospital Pharmacists, 1991: 1715.

30 Bende S, Bertok L. Elimination of endotoxin from the blood by extracorporeal activated charcoal hemoperfusion in experimental canine endotoxin shock. Circ Shock 1986; 19: 239-44.

31 Gathiram P, Wells MT, Brock-Utne JG, Wessels BC, Gaffin SL. Prevention of endotoxaemia by non-absorbable antiSL. Prevention of endotoxaemia by non-absorbable
biotics in heat stress. F Clin Pathol 1987; 40: 1364-8.

32 Gathiram P, Wells MT, Brock-Utne JG, Wessels BC, Gaffin SL. Oral administered nonabsorbable antibiotics prevent endotoxemia in primates following intestinal ischemia. f Surg Res 1988; 45: 187-93. 